\title{
1. The Missionary Home as a Pulpit: Domestic Paradoxes in Early Twentieth-Century Korea
}

\author{
Hyaeweol Choi \\ The Australian National University ${ }^{1}$
}

The English phrase "home, sweet home" was widespread in the Korean print media by the late 1920s. It signified a loving modern nuclear family with a husband and wife and their children living in a modern house (munhwa chut'aek; literally culture house) in peace and harmony. ${ }^{2}$ Articles describing celebrities' "home, sweet home" were frequently featured in popular magazines, offering an idealised form of modern family life. The first issue of the magazine, Sin Kajŏng (New Family), even included the musical notation for the song Home, Sweet Home. ${ }^{3}$ The adoption of the phrase "home sweet home" signals a shift in the conception of domestic lifestyle. This image stands in sharp contrast with the centuries' old Korean tradition of the extended family in which several generations would live together in a single household. The traditional family model followed a rather rigid code of proper behaviour in which the wife was expected to obey her husband and serve her in-laws with utmost dedication. Even the architecture of the traditional Korean house, especially that of the upper classes, physically separated living quarters for women and men with women housed in the inner chambers (anch'ae) and men residing in the outer chambers (sarangch'ae). Given this long-standing tradition, the new form of domesticity presented women with a stark contrast to the traditional domestic arrangement that meant close scrutiny by in-laws and the absence of love-based conjugal intimacy. In this vein, the emergence and popularity of the idea of "home, sweet home" deserves close analysis within the context of changes in domestic life in modern Korea.

In this chapter, I explore the genealogy of the idea of the modern home in turn-of-the-twentieth-century Korea within the context of Korea's encounter

\footnotetext{
1 This chapter draws on both Korean and English archival sources that include newspapers, journals, magazines and minutes of the annual meetings of missionary groups in Korea. They include: Minutes of the annual meetings of the Woman's Conference of the Methodist Episcopal Church in Korea, General Commission on Archives and History, The United Methodist Church, Drew University, Madison, New Jersey; Gospel in All Lands; The Korea Magazine; The Korea Methodist; The Korea Mission Field; The Korea Review; Woman's Work; Woman's Missionary Friend; Noble Journals (Mattie Wilcox Noble); Kaebyŏk; Sin kajŏng; Sin yŏsŏng; Tonga ilbo; and Yǒsŏng.

2 Ch'oe Pyŏngt'aek and Ye Chisuk, Kyŏngsŏng rip'ot'ŭ (Capital Report), Seoul: Sigongsa 2009.

3 Yi Paeyong, Han'guk yŏksa sok ŭi yŏsŏngdŭl (Women in Korean History), Seoul: Ŏjini, 2005.
} 
with American Protestant missionaries. I specifically examine the role of the missionary home as a model for what would constitute modern family and home life. In doing so, I map out the trajectory through which a new conception of domesticity moved from missionary homes to Korean homes mediated by native Bible women and experts in home economics, which emerged as an academic discipline.

One of the main goals American women missionaries had for their evangelical work was the establishment of "true Christian homes" as the foundation of true civilisation. Dana Robert demonstrates how the idea of the Christian home played a crucial role in shaping Anglo-American missionary thought and practice from the early nineteenth to the mid-twentieth century. It provided missionary women with a powerful rationale "for the participation of women in all aspects of mission work, including homemaking, evangelism, fund-raising, teaching, and even social reform." ${ }^{\prime 4}$ There is a certain paradox in the fact that these women who were holding up the ideal of domesticity were also frequently engaged in work outside the domestic sphere. This paradox is also found among those local women who were converted to Christianity by missionary women. While the missionary message and teachings centred on domestic values and religious piety in "women's work for women," local women did not confine what they learned from those teachings to the domestic sphere. Just like their missionary teachers, for some of the newly converted local women the acquisition of the skills of modern domesticity became a gateway for novel opportunities in the public domain as teachers, nurses, Bible women and social workers. Domestic paradoxes arose out of the tension between the idealised role of women in the private domain of the family and the new opportunities that arose for women to engage in public action.

Much scholarship has suggested that the boundary between the public and the private is fluid and that there is a gap between dominant gender ideology and women's actual lives. ${ }^{5}$ Furthermore, as Elizabeth Thompson argues, the

4 Dana Robert, "The 'Christian home' as a cornerstone of Anglo-American missionary thought and practice," in Converting Colonialism: Visions and Realities in Mission History, 1706-1914, ed. Dana L. Robert, Grand Rapids: William B. Eerdmans Publishing Company, 2008, pp. 134-65, p. 136.

5 Comparative histories of gender have shown that the division between public and private is a rather modern construct. Prior to the modern era, the majority of women, most often peasants, played a significant role in the productivity of the self-sufficient family unit. Furthermore, women's moral influence and their significant role in family rituals and management in pre-modern periods stretched far beyond the private domain. It is only with the rise of modern capitalist industrialisation and urbanisation that a gendered division of labour, that assigned men to the public sphere and women to the private, arose. The development of a gendered division of labour has illuminating precedents. Barbara Welter's 1966 analysis of the "cult of true womanhood" demonstrates how white middle-class women in the US and Great Britain in the nineteenth century colluded in the ideology of domesticity, a dogma they valued, even cherished. What is perhaps more important is that even this modern construct of gendered boundaries is fluid. Problematising the rigid division between the private and the public in the modern era, historians have offered examples that illustrate how domesticity is not always limited to family life. See Catherine Hall, "The history of the housewife," in The Politics of Housework, ed. Ellen Malos, London: Allison and Busby, 1980, pp. 44-71; Barbara Welter, "The 
already dynamic relationship between the public and the domestic was further intensified with the advent of imperialism. Transnational colonial encounters and foreign missionary enterprises further triggered and contributed to a major shift in perspectives on the proper space for women and men and their engagement in the family and the broader society. ${ }^{6}$

Building on previous studies, I specifically investigate the ways in which the transcultural encounters between Korean women and American missionary women transformed the domestic arena. At the abstract level, both Koreans and missionary women shared the idea that their proper space would be in the domestic sphere; ${ }^{7}$ however, they were a world apart in the material, social and cultural conditions they had in their respective domestic spheres. Ellasue Wagner, a Southern Methodist missionary in Korea from 1904 to 1940, expressed the American viewpoint in a 1908 article for a missionary magazine describing the typical Korean house as "dingy, dark, and generally very dirty ... we say that a Korean woman has no home, only a house [emphasis added]." ${ }^{8}$ In the eyes of Koreans, in contrast, the missionary home must have seemed palatial, large and filled with exotic furnishings. The wide gap in material conditions between the missionary home and Korean household further highlighted vastly different cultural practices in marital relationships, household management and childrearing. In this vein, the transcultural encounters between Koreans and American women missionaries triggered a major shift in perspectives on domestic ethics and practices. ${ }^{9}$

The chapter starts with the initial experiences Koreans had with missionary homes and then traces the ways in which the missionary model was further propagated, hybridised and institutionalised by Korean "Bible women" and a new class of Korean women who had been trained in "home economics" at mission schools to become rational, professional and scientifically-minded housewives. Examining both discourses about and experiences of domesticity, I argue that the transcultural interactions between American missionaries and Koreans are best characterised as a creative tension between devotion to the private domain and active public engagement. That is, while such interactions

\footnotetext{
cult of true womanhood: 1820-1860," American Quarterly 18(2) (1966): 151-74; Leonore Davidoff, “Gender and the 'great divide': public and private in British gender history," Journal of Women's History 15(1) (2003): 11-27; Mary Ryan, "The public and the private good: across the great divide in women's history," Journal of Women's History 15(2) (2003): 10-27; Elizabeth Thompson, "Public and private in Middle Eastern women's history," Journal of Women's History 15(1) (2003): 52-69.

6 Thompson, "Public and private in Middle Eastern women's history."

7 Hyaeweol Choi, Gender and Mission Encounters in Korea: New Women, Old Ways, Berkeley: University of California Press, 2009.

8 Ellasue Wagner, “A Korean home," The Korea Mission Field 4(6) (June 1908): 90.

9 Thompson, "Public and private in Middle Eastern women's history."
} 
reinforced the assumption that women belonged in the domestic arena, they simultaneously allowed women to engage at the national and even global level and thus to challenge established gender boundaries.

\section{"The plainest missionary home is still a palace in the eyes of the native"}

In 1908, Mattie Noble, a prominent woman missionary who was in Korea from 1892 to 1934, wrote in her diary that "a Christian home in a non-Christian land is a great object lesson." ${ }^{10}$ That idea formed the basis for a strategy in which the missionaries were able to take advantage of the Koreans' curiosity about the missionaries, their lifestyle, their dwellings and furnishings; they used their homes as models to illustrate the virtues of a Christian household. With the arrival of Western missionaries in the late nineteenth century, the missionary home became an object of curiosity among Koreans. One missionary suggested that the furnishings and the practices were so peculiar and so exotic that the Korean visitors took the missionary home to be the fanciful residences of "mountain spirits."11 To missionaries, the things commonly found in their homes-chairs, tables, rugs, sewing machines-were ordinary everyday household items; however, local people had never seen such paraphernalia and, for the most part, did not have the means to possess such things. As Annie Baird, a long-serving missionary who was in Korea from 1891 to 1916, noted, "The plainest missionary home is still a palace in the eyes of the native." 12 The exotic furnishings were more than a simple curiosity; they were exotica coveted by Korean visitors. Many Koreans made spontaneous "sightseeing" visits to the homes of missionaries to see all of that extraordinary stuff. ${ }^{13}$ Rather than seeing these visits as an inconvenience, the missionary woman looked upon them as opportunities to introduce the new religion to their captive audience. In her 1909 book Daybreak in Korea, Baird vividly describes one of these visits. A group of local women, led by a female shaman, asked to take a peek inside the missionary home having heard about all of the exotic things that could be found in foreigners' houses and the new "doctrine" (read Christianity) that the missionaries had brought to Korea. The missionary woman invites the local women in to explore, allowing them free reign to examine the household items. However when she tries to introduce the new religion, to her dismay,

10 Mattie Noble, Noble Journals, The General Commission on Archives and History, the United Methodist Church, Drew University, 1892-1934, vol. 4, p. 3a. The entry is titled "Pyeng Yang School April 1908," in which Noble made a plea to potential donors in the US in support of the establishment of a foreign school for missionary children in Korea.

11 Annie Baird, Daybreak in Korea, New York: Fleming H. Revell Company, 1909, p. 60.

12 Annie Baird, Inside Views of Mission Life, Philadelphia: Westminster Press, 1913, p. 25.

13 Baird, Daybreak in Korea, pp. 58-63. 
the Korean visitors continually interrupt her to ask questions like "How old are you?" "How many children do you have?" or "Are your parents living?" which she describes as "irrelevant." ${ }^{14}$ What's more, the Koreans do not sit and listen compliantly. When the missionary woman says, "You all know about God, of course?" the Korean shaman reacts "with strong traces of resentment," saying, "Who doesn't know about God?... Do you take us for animals?"15 In the end, the missionary's tenet that Jesus Christ is the only "Lord and Saviour" was challenged by Koreans' polytheism. In Baird's account, for the Koreans, "The more objects of worship the better," and thus the local women decided to "just worship him (Jesus Christ) along with all the rest." ${ }^{16}$ Such interactions indicate that the missionary home was a dynamic site in which vastly different material, religious and cultural thoughts and practices were assessed and negotiated for use in the local context.

In addition to welcoming these spontaneous "sightseeing" visits from the Koreans, the missionaries also offered invitations to local Koreans for more planned events. Mattie Noble, who kept a diary over the forty-two years of her service in Korea, describes one particular incident in a journal entry around Christmas in 1893. She writes how she wanted to invite the local women into her home to introduce the holiday. She had her Korean teacher "write me a nice invitation to my neighbor women to come in the afternoon." To her surprise, "more than I invited heard of my plan" and "more than fifty women besides children" came. She prepared a table "well loaded with nuts, oranges and cakes" and borrowed from her missionary colleague a "baby organ." She describes how none of the Korean visitors had heard about Christmas or Jesus, and she says, "What an opportunity to tell them the story.... I wanted to win their hearts for Jesus and let them see that we foreigners loved them." She describes how she led her visitors in songs and prayer, after which she offered refreshments, which "the poor heathen women and children enjoyed." To Noble, the Koreans' overwhelming positive response to her invitation was a sure sign that this initial friendly encounter would certainly make Koreans welcome her into their homes more heartily. ${ }^{17}$ She feels that her gambit paid off, as she reports that her experiences from home visitation brought her "in touch and sympathy with the women as no other work" did. ${ }^{18}$ From these accounts it is clear that in these early encounters, the missionary home acted as a transnational space in which Koreans came into contact with a new form of domesticity that incorporated modern material conveniences and the new religion.

14 Ibid., pp. 62-63.

15 Ibid., p. 62.

16 Ibid., p. 63.

17 Mattie Noble's journal, 25 December 1893. See also D.L. Gifford, Every-Day Life in Korea, New York: Fleming H. Revell Company, 1898, pp. 148-49.

18 Mattie Wilcox Noble, "Report of Evangelistic work, Bible Institutes, and Three Day Schools, Pyeng Yang," Annual Meeting of the Woman's Conference of the Methodist Episcopal Church in Korea in 1906, pp. 60-65. 


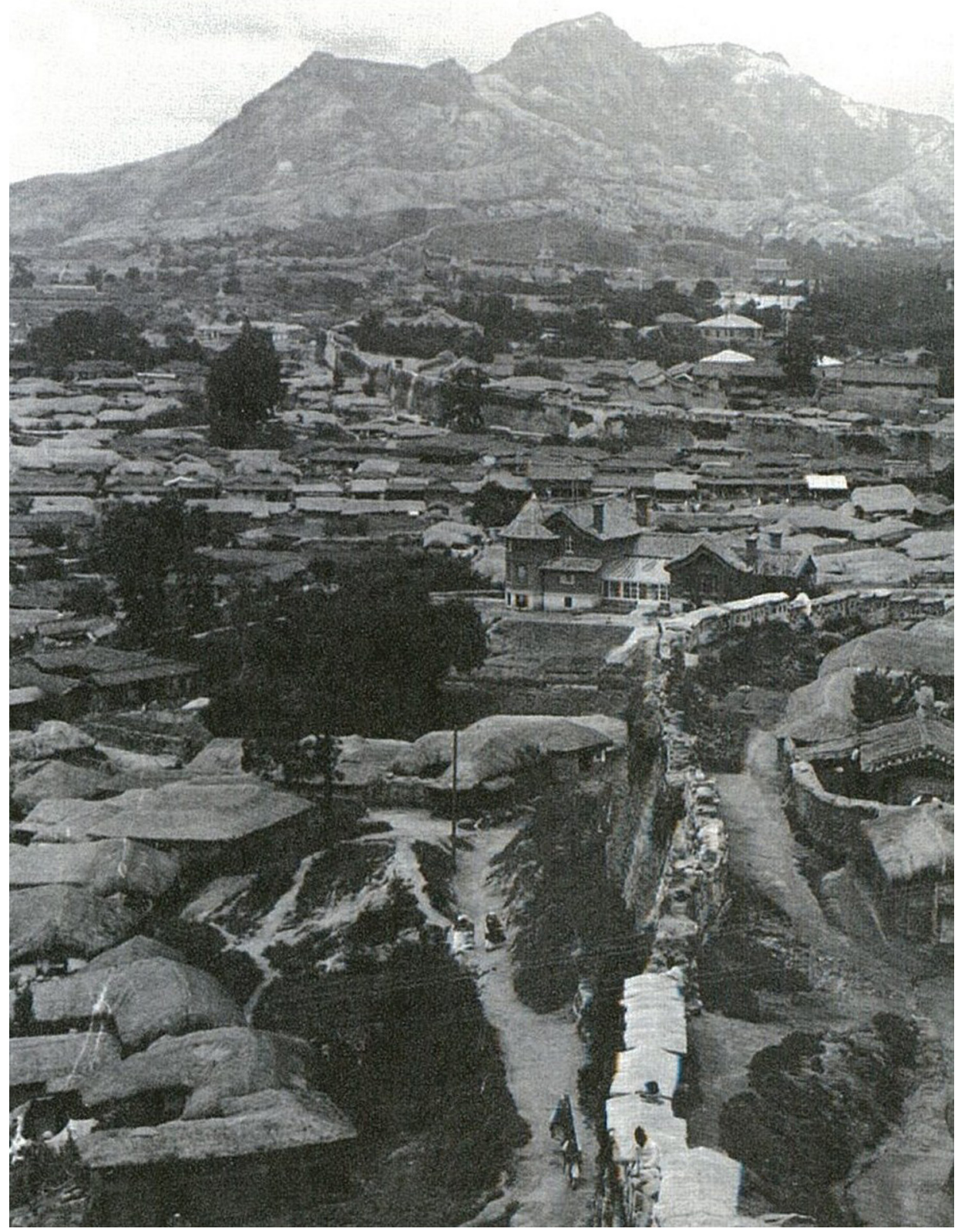

Figure 1. Horace Underwood's Western-style house

Source: Sung-deuk Oak, Hanbando tae puhŭng, Seoul: Hongsŏngsa, 2009, p. 41. 


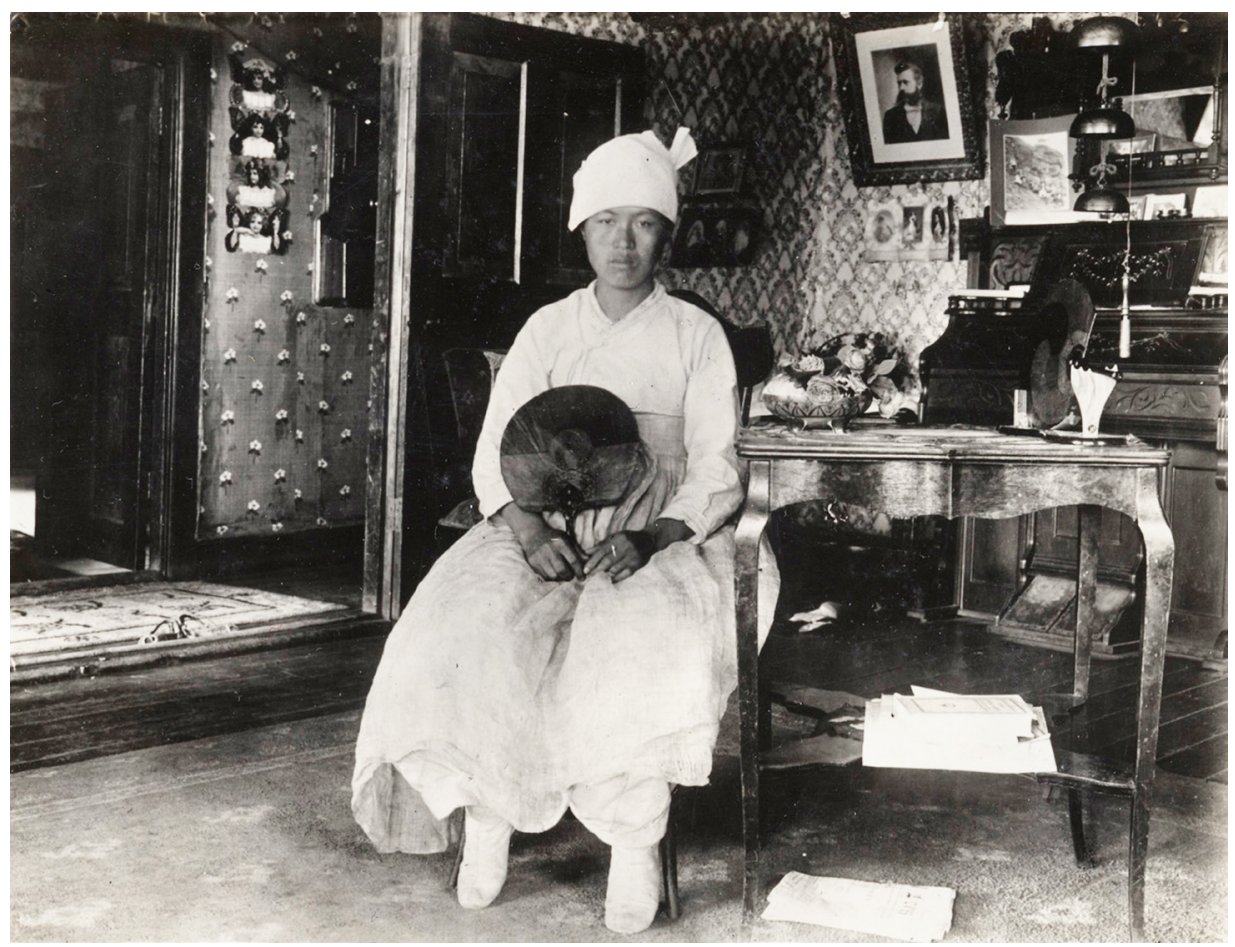

Figure 2. Missionary home interior, featuring unidentified woman

Source: The Reverend Corwin \& Nellie Taylor Collection, University of Southern California, Los Angeles.

In the early period of the mission, missionaries often lived in houses that were in the style of the Korean upper class (yangban) and families of wealth, with some minor interior renovations such as installing glass windows, which did not exist in the traditional Korean house. However, it was not long before they began to build Western-style houses for their residences (Figure 1). These houses were typically funded through an appropriation by the foreign mission board, but some missionaries used their own private funds to build rather grandiose structures, which often drew harsh criticism from Western visitors passing by. ${ }^{19}$ Often located in the most sought-after sites, missionary houses prominently stood out amid the humble, thatch-roofed Korean huts. ${ }^{20}$ Prolific nineteenth-century world traveller, Isabella Bird Bishop (1831 to 1904), reports that French Catholic missionaries lived "in the wretched hovels of the people,

19 Katherine Ahn, Chosŏn ǔi ŏdum ŭl palk'in yŏsŏngdŭl (Awakening the Hermit Kingdom: Pioneer American Women Missionaries in Korea), trans. Kim Sŏngŭng, Seoul: P'oiema, 2009, p. 174.

20 Baird, Inside Views of Mission Life, p. 26; Ahn, Chosŏn ŭi ŏdum ŭl palk'in yŏsŏngdŭl, p. 26. 
amidst their foul surroundings, and shar[ing] their unpalatable food and sordid lives."21 In contrast, American Protestant missionaries were for the most part living in houses that were substantial and reasonably comfortable.

In order to maintain their standard of living, missionaries would bring with them or import from the US the accoutrements of fine Western homes. ${ }^{22}$ The missionary homes were typically equipped with modern Western furniture and artefacts that very few Koreans had ever seen before. A photograph of a Korean woman (Figure 2) illustrates some of the details of the missionary home interior, which typically included chairs, books, lamps, clocks, framed photographs, rugs and richly patterned wallpaper, but in some instances might also have contained such unusual furnishings as an organ, a furnace, a sewing machine or a typewriter. ${ }^{23}$ As Dae Young Ryu demonstrates, the majority of missionaries came from the middle class or at least strove to obtain the status of the middle class, and most of them "endeavored to retain their American middle-class lifestyle" in the Korean mission field. ${ }^{24}$ Thus, their furniture and other household items were very important in maintaining their middle-class identity and their standard for "a civilized lifestyle." Not only home interiors but food and daily goods were also imported in bulk from companies like Montgomery \& Ward in Chicago so they could continue their Western diet and lifestyle. ${ }^{25}$ Arthur Brown, General Secretary of the Presbyterian Board of Foreign Missions from 1895 until 1929, viewed American products as important economic means for introducing Western civilisation to mission fields and developing "desire" for these modern material products and ultimately for the lifestyle with which they were associated.$^{26}$ In a significant way, the furnishings and goods that could be found in the missionary household offered Koreans a glimpse of the modern home and a new lifestyle that would have been attractive even though it was not immediately available to the vast majority.

The missionary home put on display not only a drastically different material culture but also new kinds of marital relationships and child-rearing principles. From the missionaries' viewpoint, the Korean ideal home differed from the

\footnotetext{
21 Dae Young Ryu, “Understanding early American missionaries in Korea (1884-1910): Capitalist middleclass values and the Weber thesis," Archives de sciences sociales des religions 2009, (En ligne), 113 | janviermars 2001, mis en ligne le 19 août 2009, URL: http://assr.revues.org/20190, accessed 16 May 2012.

22 Baird, Inside Views of Mission Life, p. 27.

23 Arthur J. Brown, The Mastery of the Far East: The Story of Korean's Transformation and Japan's Rise to Supremacy in the Orient, New York: Charles Scribner's Sons, 1919, p. 471. See also Baird, Inside Views of Mission Life, p. 27.

24 Ryu, "Understanding early American missionaries in Korea," p. 98. See also A. Deacon and M. Hill, "The problem of surplus women in the nineteenth century: secular and religious alternatives," in A Sociological Year Book of Religion in Britain, no. 5, ed. D. Martin, London: SCM Press, 1972, pp. 87-102.

25 Mattie Noble's journal, 22 October 1892; 22 June 1897; 6 December 1897. American missionaries also celebrated the Fourth of July, gathering together and enjoying "fireworks, we shot off a few fire crackers.... sang patriotic songs, and were treated with ice cream \& cake." Mattie Noble's journal, 15 July, 1893.

26 Brown, The Mastery of the Far East, p. 471.
} 
American in virtually every aspect. ${ }^{27}$ To begin with, the arranged marriage system in Korea was in conflict with the love-based marriage advocated by American missionaries. Mary Cutler, a medical missionary in Korea from 1892 to 1939 , conveys the missionary discomfort with Korean practices, saying that the "marriage customs here seem dreadful to those who have been acquainted with Christian rites. The bride has never seen the man whom she promises to honor, love, serve and obey." ${ }^{28}$ In the long-held tradition of arranged marriage, a union between a man and a woman was not a matter of the two individuals but of their families. The union was determined entirely by the parents. One can find a certain paradox in the missionary critique of arranged marriage in Korea, in that missionaries themselves were often constrained by familial or congregational pressures in seeking their own marital partners. Many married hastily prior to their departure to the mission field. Indeed, single and widowed missionaries often found their spouses in the same mission field while working. To be sure, in the case of such strategic marriages, individuals still had the power to choose their partners. Even so, missionaries expressed concern that there was no proper process for the prospective bride and groom to get to know each other prior to the wedding ceremony.

As mission work progressed, missionaries began to express some relief that a Christian form of courtship and matrimony had started to put down roots. James Gale, a Canadian Presbyterian missionary who was in Korea from 1888 to 1929, noted that a "new style of courtship" had emerged among Christian Koreans in which a Christian man and woman would exchange correspondence filled with quotations from Christian tracts to express their love and commitment to each other, foregoing the traditional match-making arranged by parents. Indeed, to the missionaries, the very basis of a Christian home began in the union of a Christian man and a Christian woman. This Christian home in turn offered the promise of proliferating and consolidating the Christian population. ${ }^{29}$ Missionary teachers often worried about the possibility of their students marrying nonChristians. In this vein, the ideal union was one between graduates of Ewha Girls School and Paejae Boys School, both Methodist-run mission schools in Seoul. The medical missionary Mary Cutler pointed out that a woman who has married is said in Korean to have "gone to her mother-in-law" rather than creating her own home - a concept for which she claimed Korean had no equivalent term. Therefore, from the missionary viewpoint, the Christian home created a new ideal domesticity without "heathen characteristics." ${ }^{30}$

\footnotetext{
27 “Home life in Korea," Woman's Work 16(11) (1901): 301.

28 Mary M. Cutler, “A Korean wedding," Woman's Missionary Friend 37(4) (April 1905): 131-32.

29 Minutes of the Third Annual Meeting of the Korea Mission of the Methodist Episcopal Church, held in Seoul, 9-14 May 1901, pp. 2-3.

30 Cutler, "A Korean wedding."
} 
In a 1931 article in The Korea Mission Field, Mattie Noble wrote with pride that "the Christian home cannot hide its light. Glimmers from it are carried away by visitors and workers in the home and too far away towns and villages." ${ }^{11}$ She describes running into a Korean man who had visited her house only once twenty years prior. He told her how he had become a Christian "through the influence of that one visit years before" and how it had inspired him to put "more beauty and cleanliness into his own home." ${ }^{\prime 32}$ To Noble, her own home was no longer a private space for the exclusive use of her family. Rather it was a public space, a model and a laboratory for the training of Korean converts and employees. Early on, she envisioned the missionary family serving as an ideal for Koreans to look up to and emulate. For her, the relationship between the missionary husband and wife demonstrated the ideal of companionship, in which the wife no longer has to be subservient but rather enjoys a fuller life with her husband, which was very different from the conventional marital relationship in old Korea. ${ }^{33} \mathrm{In}$ addition, the mission home exemplified the proper behaviour of children and good parenting. When Noble held classes at her home, Korean women often brought their children. She found that Korean children were "left untrained," breaking things and acting like tyrants with their mothers. Noble "gave them [the mothers] a little talk on the government of children," and she saw it begin to have some effect as Korean mothers started to discipline and punish children for their unruly behaviour. ${ }^{34}$

Noble sums up the gradual but lasting impact of the missionary home on the Korean woman and family:

She [the Korean woman] is learning, and she sees the bearing out of this truth in concrete, tangible form in the missionary home, by observing the wife and mother, - her freedom, her love, her authority ... this missionary mother has met people who have told her how, in the raising of the children, they have taken pattern after some methods they had seen used in the raising of children in the missionary home. ${ }^{35}$

Noble asserted that "the home shapes the civilization. Women make the home," and missionary homes are important grounds "for the redemption of the heathen woman." 36

This presumed influence emanating from the missionary home was possible in part thanks to the servants and maids they hired locally. In his account of

31 Mattie Wilcox Noble, “The missionary home," The Korea Mission Field 27(4) (1931): 75-77.

32 Noble, "The missionary home," p. 76.

33 Mrs. A.M. Sharrocks, "Work among Korean women," The Korea Mission Field 2(2) (1905): 33-35.

34 Mattie Noble's journal, 1 February 1897.

35 Noble, "The missionary home," pp. 75-77.

36 Jennie Fowler-Willing and Mrs. George Heber Jones (Margaret Bengal Jones), The Lure of Korea, Boston: Woman's Foreign Missionary Society, Methodist Episcopal Church, 1910, p. 7. 
the day-to-day existence of American missionaries in Korea, Daniel Gifford, who served in the Korean mission field from 1888 to 1900, says that "as a rule, [missionaries] live with the same simplicity as ministers in the country villages of America." However, there was one significant exception: missionary families hired servants, a practice that was associated with middle-class families in the US. Gifford notes that "the customs of the country require them [missionaries] to keep, at low wages, two or three servants." ${ }^{37}$ While he does not offer any deeper explanation of this "requirement," it can be inferred that having servants was an expedient strategy by which missionaries could gain respect from the local community because the ability to hire servants suggested means and statusstatus that would have been equivalent to that of the upper class in the eyes of local Koreans. In addition, helping hands from Korean servants would have been essential for missionaries who were not familiar with the Korean lifestyle.

However, as Gifford implies, missionaries were aware of the basic contradiction between the simple life like that of their counterparts at home and a comfortable, even luxurious life surrounded by many servants. ${ }^{38}$ Baird provides a detailed rationale for hiring servants in Korea. She says that ideally missionaries would do their work wholly on their own, but "as time passes on and our mental vision clears, we begin to see that the cheapest and most plentiful thing under heathen skies is human manual labor, and the scarcest and most precious is missionary time and strength." More importantly, she continues, "We will soon realize, too, with an intensity that is almost painful, that we are face to face with the most difficult undertaking of our whole lives, the acquisition of an Eastern language, and we begin to see that upon the acquisition of this language, by ourselves and others like us, depends the eternal and in a large sense the temporal welfare of a whole people." 39 Emphasising the priority of evangelisation as more deserving of the time and energy of the missionaries, Baird argues that utilising the cheap and plentiful labour from local people offers greater benefits than the general principle of leading a simple and humble life. She even argues that those who decide "to dispense with servants altogether" and adopt a plainer but more laborious option (doing their own work) "are not able, as a rule, to prove that they can become as efficient missionaries." 40

To be certain, a missionary wife's domestic responsibilities might have prevented her from engaging in her original evangelical ambitions outside the home, especially when she had the responsibilities of child-rearing. ${ }^{41}$ However, a squad of servants ready to assist her with domestic chores would afford her

\footnotetext{
37 Gifford, Every-Day Life in Korea, p. 157.

38 Baird, Inside Views of Mission Life, p. 22.

39 Ibid, p. 23.

40 Ibid, p. 24.

41 Gifford, Every-Day Life in Korea, p. 157; Jane Hunter, The Gospel of Gentility, New Haven: Yale University Press, 1984, p. 100.
} 
more time to devote to evangelical purposes. In fact, the domestic space of the home became a legitimate and expedient venue for achieving both religious goals and domestic projects. ${ }^{42}$ In this vein, it is illuminating to look at Mattie Noble's typical daily routine. Her diary entry for February 11, 1908 includes an outline of that day's schedule:

a.m. Planned for the Household for the day.

Working on a Montgomery Ward \& Co. order for the household for six months' use.

Call from a Bible woman and consultation over the work.

12. m. Attended an ordination service at the Church. Mr. Rufus was ordained Deacon.

2 to 3:15 Held a women's meeting.

4:00 Attended an infant baptism service (Evelyn Becker's).

7:00 p.m. Attended the revival service at the Church.

We can see that her day was split between household planning in the morning and training and outreach activities in the afternoon and evening. The ready availability of servants at extremely low cost - five dollars per month was the average wage for a servant - certainly enabled the missionary wives to use more of their time and energy for the "welfare of a whole people." ${ }^{43}$

While the presence of household help offered some freedom for the missionary wives to engage more directly in the work of the mission, it was not without problems and frustrations. The missionaries had their own sense of the ideal domestic state and proper domestic practices, and they frequently expressed chagrin, even anger, at the inability of the uninitiated Koreans to live up to Western standards. Noble referred to the training and working with servants as "our great trial out here" because of the Koreans having "so much disease and lice and being so stupid." 44 She wrote extensively about her largely negative experiences with servants in her home, especially in her early years in Korea. She hired local men and women as cooks, housekeepers and babysitters (amah). Since these Koreans had no experience with Western-style domestic practices, she had to teach them almost everything. By the time the Nobles arrived in Korea in 1892, Korean cooks had recipes for Western dishes available to them in

42 Mary Taylor Huber and Nancy C. Lutkehaus, "Introduction: gendered missions at home and abroad," in Gendered Missions: Women and Men in Missionary Discourse and Practice, ed. Huber and Lutkehaus, Ann Arbor: University of Michigan Press, 1999, pp. 1-25, p. 13.

43 Baird, Inside Views of Mission Life, p. 63.

44 Mattie Noble's journal, 17 October 1894. 
Korean. Still they needed a great deal of training. One day Noble was planning a dinner for three guests and ordered a menu: tomato soup; canned beef, fresh corn and potatoes and canned peas; canned pineapples, ice cream and nuts and lemonade. She thought the cooks "ought to do very well" given the recipes in Korean, but she expressed dismay at the cooks' inability to follow instructions properly and complete the menu. ${ }^{45}$ She describes Korean cooks and servants as dirty, untrustworthy, and very slow to learn. In a journal entry she offers a list of items that had been stolen from her family by Korean domestic workers. ${ }^{46}$ In another entry she recounts the discovery that two of the people she had hired as servants - one as an amah and the other as a cook - were found to have syphilis. She wrote in her journal in 1894:

Our Amah and Boy had great body lice, ${ }^{47}$ and I had commanded them to get rid of them or they could not stay. We thought it no use to send them away, as the next ones we hired might in all probability be the same, but today found out that they have syphilis, and now they must go. Oh, how badly I feel that they have been here at all. She has very, very little to do with our baby and how glad I am that it is so. Arthur says that these people are making us distrustful, for the great majority deceive so. ${ }^{48}$

Her frustration is summarily expressed in her journal entry of December 6, 1897. She writes, "I am sick and tired of these cheating, thieving dull people. Every once in a while I get such a nervous headache over their exasperating ways, I don't know what to do. Everything that is bought wears one because they cheat so." At the same time, she wonders, "But why do I write so, I do love the people, and thoroughly enjoy doing for them and teaching them, and consider it a great privilege, but I do think that I will get old and gray-haired sooner than if we lived in America." ${ }^{49}$

She remarks on her discontent and frustration with the wide gap between her own standard of domestic management based on the lifestyle of the white middle-class family in America and certain realities she faced in Korea. However, at the same time she expresses guilt over complaining about Korean hired help. Over time, her "great trial" in the handling of her servants subsided, perhaps because she gained a firmer grip on the training and management of servants and communicating her preferences about domestic style to them, or perhaps because the Western style of domesticity became more familiar and more commonly practised among Korean locals.

45 Ibid., 28 July 1893.

46 Ibid., 11 January 1895.

47 Noble calls male servants "boys."

48 Arthur Noble is Mattie's husband. Mattie Noble's journal, 17 October 1894.

49 Mattie Noble's journal, 6 December 1897. 
Despite the trials that missionaries had with servants, the hard work, faithfulness and full dedication of these servants to missionary families were vital for the daily lives of missionaries in Korea. In fact, Annie Baird suggested that difficulties with servants arose "not from unwillingness to serve but from overwillingness." ${ }^{50}$ For a meagre monthly wage of five dollars, servants did practically everything - cooking, sewing, cleaning, delivering mail, carrying water from a distant well, cutting wood and cultivating gardens. As the missionary home frequently played host to visiting dignitaries, servants were often responsible for preparing and cooking for quite lavish dinner parties featuring Westernstyle menus and service. ${ }^{51}$

And over time some servants and amahs came to do more than simply work to maintain the household. Edith Parker Johnson, a Northern Presbyterian missionary who was stationed in Korea from 1897 to 1913, marvelled at the effective and sincere work of her amah, who led a prayer session for visiting local women in her home. She wrote:

One day some women came saying they wanted to learn about the Jesus doctrine. After talking to them for some time, I called in the amah to tell them the story of Christ in better Korean than I could muster. She spoke a few words and then, to my astonishment, said: "Let us bow in prayer,"... she offered prayer ... Christian women in America with centuries of Christian training behind them, sometimes find it difficult to lead in prayer before others, so I think our amah has begun well her Christian life. ${ }^{52}$

Examples like this demonstrate how the missionary home evolved into a place where training in a modern form of domesticity and successful evangelisation came to be intermingled. While working as servants and amahs, Korean employees were not only instructed in how to serve and maintain a household in the Western style but also became perhaps the most intensive targets of the missionaries' evangelisation efforts. Some of them later worked as Bible women, mediating between the missionary home and Korean homes. In this way, the transnational experience of modern domesticity became inextricably bound together with Christian doctrine.

\footnotetext{
50 Baird, Inside Views of Mission Life, p. 62.

51 For instance, on 12 February 1908, Mattie Noble hosted an elaborate dinner in honour of Bishop Harris, who was visiting Korea. Fifteen guests, including the Korean Governor in P'yŏngyang and the Japanese Resident of $\mathrm{P}^{\prime}$ yŏngyang as well as the Bishop and American missionaries, were present, and a six-course dinner was served: 1. Bouillon; 2. Steamed fish with white dressing and mashed potatoes; 3. Roast bustard and potatoes, dressing, baked beans, cabbage salad, and gravy; bread, jam, and pickles; 4. Pumpkin pie; 5. Oranges, apples, and peanuts; and 6. Coffee.

52 Woman's Work 15(11) (1900): 306-07.
} 
The missionary home served as an informal pulpit as well as a model for imparting what constitutes the "ideal home." As an anonymous "missionary wife" claims, "the missionary's wife ... knows how to make home the dearest, sweetest and most charming spot in all the world for the inmates of that home. Who can measure the influence of a well-ordered home in a heathen land?"53 A missionary wife would hire local women to cook, clean, sew and do laundry. These hired local women then had to be trained to perform the household tasks as an American housewife would do them, so the missionary household became a site through which these domestic ideals came to be known and practised by Koreans. ${ }^{54}$ Furthermore, it was often in the missionary home where missionary wives could engage in the evangelisation efforts of the mission. These missionary wives opened their homes to offer Bible classes for the converted, to train Korean Bible women, to hold sewing classes during which they would discuss the gospel, and to bring young people in for choir practice. ${ }^{55}$ In addition, Korean visitors or workers observed new disciplinary methods in child rearing. While the wealth of cultural and material experience that could be found in the missionary home certainly had an impact, it is also important to note that a relatively small number of Koreans had the opportunity to actually visit one. In this context, those Korean servants, amahs and the other local women who received certain training from missionaries became an important conduit between the missionary home and the greater Korean population. In this regard, the role of the Bible women was perhaps most prominent as the mediator in bringing together the different lifestyles and negotiating the tensions that existed between them.

\section{Evangelising modern domesticity}

The term "Bible women" (chŏndo puin) refers to those Korean women who had converted to Christianity and shown such dedication to church work that they were hired with mission funds to serve as personal helpers to women missionaries and work under missionary supervision. ${ }^{56}$ Their primary task was to bring the Bible and religious tracts to Korean women through a program of home visitations, often in remote villages. The number of missionaries was always limited, and they were largely stationed in bigger cities. Because of these limitations in personnel, it was difficult for missionaries themselves to visit places far away from their mission station. It was Bible women who filled this void, and they became indispensable agents in propagating Christian doctrine to

\footnotetext{
53 “Missionaries' wives," The Korea Methodist 1(11) (10 September 1905): 146-47.

54 Ibid.

55 H.G. Appenzeller, "Woman's Work in Korea," Gospel in All Lands (September 1891), p. 424; The Korea Mission Field 34(11) (Nov. 1938): 233.

56 Choi, Gender and Mission Encounters in Korea, pp. 65-66.
} 
the wider population, especially those who lived in remote villages. In addition, the missionaries' limitations in linguistic and cultural proficiency often would not allow them to have satisfactory communication with local women, and the local women's suspicion or even fear of foreigners also acted as an impediment to interaction. In this vein, Kate Cooper (1908-1957) noted that "many of the country women are dependent almost entirely upon the Bible women for all their help." 57 The devotion of the Bible women to the task of delivering the gospel to the Korean people and their success in that task was a continual theme in the mission reports and personal accounts of the missionaries. Lura McLane Smith (1911-1950) wrote, "It is impossible to estimate fully the value of such work as they [the Bible women] are doing." ${ }^{18}$ Bible women showed "such aptitude in the work of rescuing others" and were willing to work for little pay, so in the minds of most missionaries "the good resulting makes the support of a Bible-woman one of the best paying investments which can be made." ${ }^{59}$ Indeed, Rosetta Sherwood Hall (1890-1935), a Methodist medical missionary in $\mathrm{P}^{\prime}$ yŏngyang, complained that "we are now obliged to pay our servants more than our Bible women receive, and that does not seem right." 60

Generally being a Bible woman was a full-time commitment. Missionaries faced great difficulty in recruiting "able-bodied, efficient women" who could devote their time fully to evangelical work. Custom forbade young women from travelling, and tradition placed heavy demands on women in their prime to perform domestic duties. ${ }^{61}$ For those reasons, widows and older women were often preferred for these positions as they had fewer family obligations and were able to travel more freely. ${ }^{62}$

The first Bible women did not all become literate; however, literacy in Korean eventually became a requirement for anyone hoping to become a Bible woman. The Bible women needed to be literate in order to read the Bible and teach it to local women. Furthermore, attaining literacy turned out to be a crucial factor in their gaining certain respect in the broader community, especially among the women with whom they interacted, as literacy was a rare achievement among Korean women at the time. While literacy in Chinese was more prestigious, Korean literacy still had value. In this context, as Nellie Pearce Miller of the British and Foreign Bible Society in Korea noted, many new local women had come to her Bible School "simply because they want to study." ${ }^{63}$

57 Kate Cooper, “The Bible woman," The Korea Magazine (January 1917): 6-10.

58 Lura McLane Smith, "Korean Bible women," The Korea Mission Field (October 1937): 213; Mattie Wilcox Noble, “Conditions in Korea," Woman's Missionary Friend 39(5) (May 1907): 172; "Bible women," The Korea Review 6 (1906): 140-47, p. 146.

59 Woman's Missionary Friend 27(9) (March 1896): 259.

60 Ibid., 38(8) (August 1906): 295.

61 "Bible women," p. 140.

62 Cooper, "The Bible woman," pp. 6-10.

63 Woman's Missionary Friend 37(8) (August 1905): 291. 


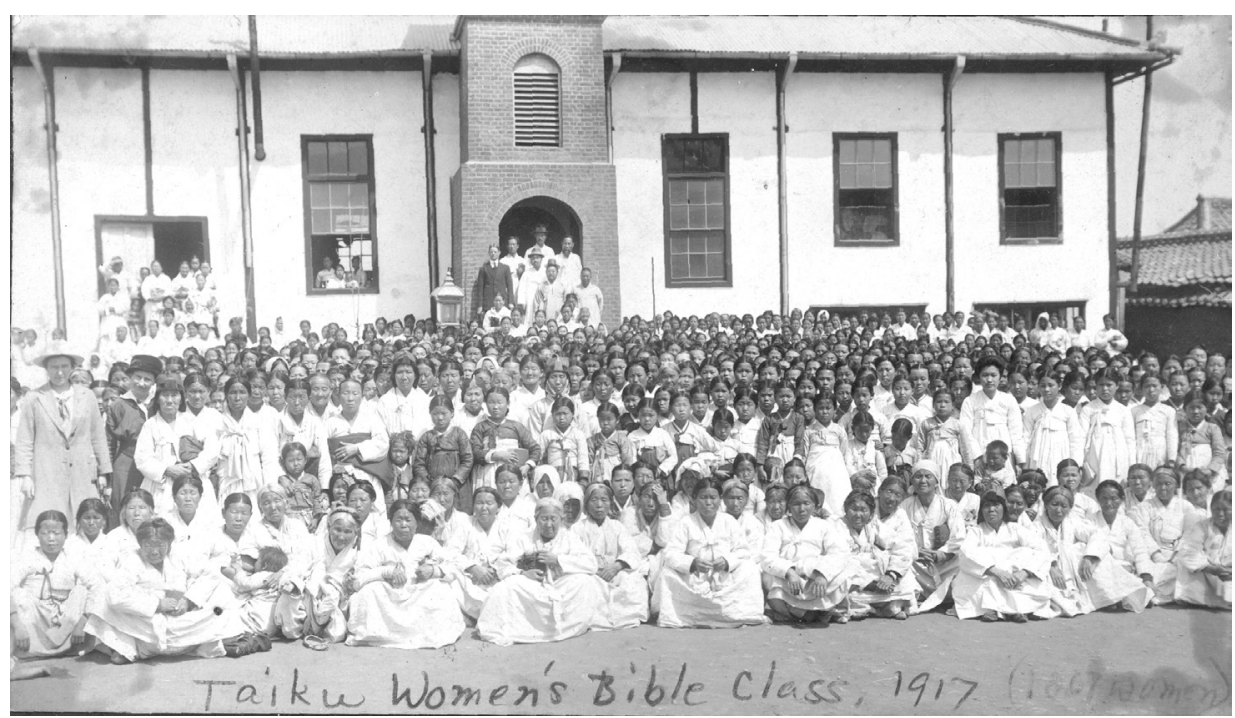

Figure 3. Women's Bible Institute, Taiku in 1917

Source: Presbyterian Historical Society, Philadelphia.

Bible women received their training from missionary women both informally in the missionary home and more formally at Bible institutes (Figure 3). ${ }^{64}$ They learned how to read vernacular Korean and received lessons on Christian religious texts in addition to receiving training in such skills as basic mathematics, writing, hygiene, physiology, cooking and care of the sick. ${ }^{65}$ They were also instructed in some principles of teaching and lesson planning. ${ }^{66}$ Women who completed the curriculum successfully were awarded a diploma. Olga Schaffer (1910-1916), a Methodist missionary, observed that "the Koreans 'love' diplomas, and their good prestige depends largely upon the possession of one or more." ${ }^{67}$ Thus the promise of a diploma acted as an inducement to "inspire faithful attendance and enthusiasm to the end." Receiving a diploma would have been an aspiration for many Korean women, and the pride they took in that achievement was reflected in the fact that they would "frame it and hang it on the wall of their little home." ${ }^{68}$ It was a public endorsement that signified these Bible women were able to read and teach. More importantly, it was a public recognition that these women were qualified to do public work.

64 Sung Deuk Oak, 'Comment,' in Sources of Korean Christianity, ed. Sung Deuk Oak, Seoul: Han'guk kidokkyo yŏn'guso, 2004, p. 188.

65 Miss Butts, “Report of workers' class of Bible Institute, Pyeng Yang," The Korea Mission Field 9(1) (1913):

11; Margaret Best, "Courses of study and rules of admission of the Pyeng Yang Presbyterian Women's Bible Institute," The Korea Mission Field 6(6) (June 1910): 152-54.

66 N.R. Scholes, “Developing women leaders," The Korea Mission Field 12(7) (1916): 187-89.

67 Olga Shaffer, “Yeng Byen Women's Bible Class," The Korea Mission Field 9(11) (1913): 284-86.

68 "A Bible Class in Seoul," Woman's Missionary Friend 53(4) (April 1921): 124-26. 
Upon completing their preparatory education, they were assigned to lead small groups of women in the study of the Bible and to perform other church activities under the guidance of the women missionaries.

Bible women took advantage of women's desire for literacy and taught han'gŭl (Korean writing system) to "those desirous of learning to read," using those lessons as opportunities to teach the Bible and the gospel during these home visits. ${ }^{69}$ And just as missionary women used their own missionary homes as a pulpit, the Bible women turned the Korean homes into pulpits. In doing so, Bible women represented a new form of womanhood that incorporated skills of literacy and teaching, public work and unprecedented mobility across various social divisions.

In addition to literacy, Bible women's modern knowledge of the work of the domestic sphere, including nutrition, hygiene, home management and childrearing were also regarded as an attractive quality. During the training sessions run by missionaries, prospective Bible women received "lessons in cooking, sewing, canning, gardening and other things for the making of a better home." ${ }^{70}$ These secular classes were sometimes open to non-Christians as well as Christians because there was significant interest on the part of local women, and missionaries saw this as another opportunity to gain converts. The popularity of the knowledge of home management and child-rearing was manifested most clearly in the work of the Seoul Evangelistic Center ( $T^{\prime}$ aehwa yŏjagwan in Korean; literally "the Garden of Heavenly Peace"), which was established in 1921 with financial support from the Boards of the Women's Foreign Missionary Society and the Women's Council of the Southern Methodist Church. The Centre offered instruction in a variety of skills, including English language, piano, organ and singing lessons, and "everything from the canning of tomato juice for their babies to the cooking of a foreign meal for the husbands." 71

Within the Centre, there were three departments: Evangelistic, Educational and Social Services and Public Health. The department of Public Health and Child Welfare, which was organised in 1924 by Elma Rosenberger (1921-1940) and her Korean assistant, was hugely popular and influential. Rosenberger recalls that when the work of public health began in 1924, "the word Public Health [original italics] was not even known" among the public. ${ }^{72}$ This public health program started with medical missionaries and their Korean assistants making visits to homes to treat mothers and their children. Newspapers reported this new practice, and word spread. In the opinion of many missionaries, Korean

69 “Bible women," pp. 140-47.

70 Bessie Oliver, "Rural evangelistic work," The Korea Mission Field 33(10) (October 1937): $211-12$.

71 Oliver, "Rural evangelistic work," pp. 211-12.

72 Elma Rosenberger, "Public health and child welfare work in Seoul," in Fifty Years of Light, Woman's Foreign Missionary Society of the Methodist Episcopal Church, Seoul, Korea, 1938, pp. 31-33. 
children were not being brought up properly and their health and well-being were often imperilled. Mrs. William B. McGill (1889-1905), a Methodist missionary, expressed concern that "Korean babies are not treated hygienically. They are exposed to all kinds of danger-falling, burning, diseases, dirt."73 In this context, the Public Health and Child Welfare program of the Seoul Evangelistic Center initiated a pioneering program that provided instruction in scientific techniques of child rearing through "weekly well-baby clinics, weekly mother's clubs, a milk station from which mothers can get supplies for their babies, free bathing station, home visitation work" (Figure 4). The importance of raising healthy children and the widespread acceptance of modern childrearing practices is reflected in the rise of the phenomenon of baby shows. When the first "Baby Show" was announced in 1925, one thousand babies were entered into the competition. ${ }^{74}$ By the late 1930s, "public health" was "blazoned on the front pages of magazines and newspapers, and regular health programs were given over the radio." ${ }^{75}$ Indeed, in the 1930s two major women's magazines, Sin Kajŏng (New Family) and Yŏsŏng (Women), which were financed by the daily newspapers, Tonga ilbo (Tonga Daily) and Chosŏn ilbo (Chosŏn Daily) respectively, filled their pages with abundant information on scientific childcare and hygienic homemaking.

Together with trained nurses, Bible women provided basic information about public health and new home management skills not only in the city streets but also in remote rural villages. Bessie Oliver (1912-1958), a Southern Methodist missionary, reported details of rural evangelical work that she and some Korean Bible women had done to help create happier homes. They established a regular set of practices that included church services accompanied by "talks on health, home improvement and other helpful subjects," as well as "sewing, knitting and cooking institutes." In order to provide the needed hands-on experience, "a Demonstration House for trying out home improvement projects" was built. It had "one room 16' $24^{\prime}$ for classes and club work and a kitchen 8 'x24', also a bedroom 8'x12'. Our house has many windows. We have tried to put in improvements and conveniences within the reach of the average Korean home., ${ }^{\prime 76}$ This Demonstration House supported itself in part with a small-scale canning business that used peas, butterbeans, corn, tomatoes and peaches produced in local gardens, an effort that was supposed to help people bring a wider variety

\footnotetext{
73 W.B. McGill, "The Korean baby," The Korean Repository (March 1898): 92. The fact that a six-year-old girl "is not weaned yet!" was also shocking to some missionaries. See Lulu Ribble Wells, "Village work in Korea," Woman's Work 17(9) (1902): 266.

74 Elma Rosenberger, “The Seoul Social Evangelistic Center," in Fifty Years of Light, pp. 28-30.

75 Elma Rosenberger, "Public health and child welfare work in Seoul," in Fifty Years of Light, pp. 31-33. By the late 1930s, the Seoul Evangelistic Center's membership reached 2,890. Members were affiliated with a variety of clubs, clinics and societies for women and children.

76 Oliver, "Rural evangelistic work," pp. 211-12.
} 
of vegetables in their diet in addition to supporting the Demonstration House. ${ }^{77}$ They also introduced a "Homes Day," which was intended to help "every church member, and as many non-Christians as we can reach to make their homes more happy; more helpful; more beautiful; more peaceful." During Homes Day, participants received booklets on how to make "better homes," including table etiquette in Korea and elsewhere, as well as lessons on games and crafts for children and first-aid. ${ }^{78}$

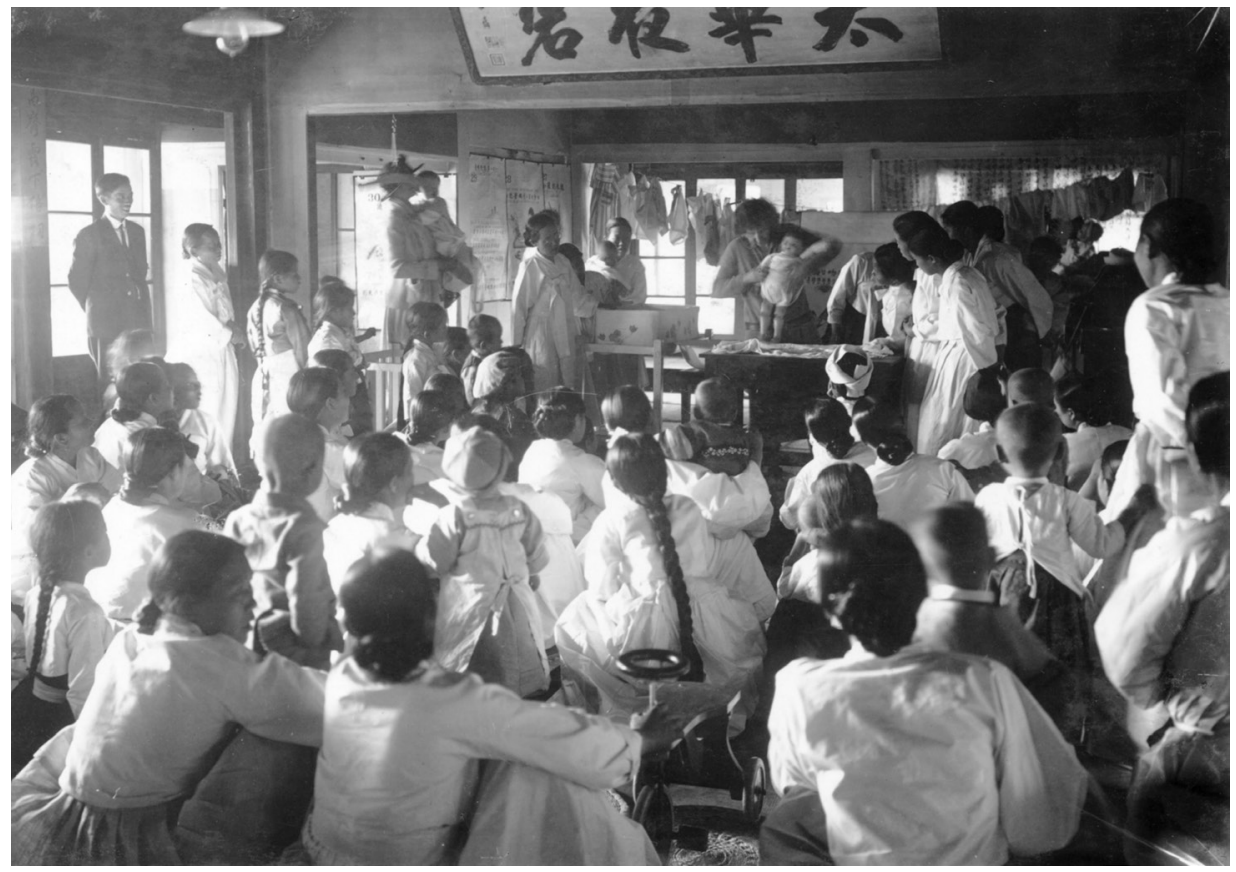

\section{Figure 4. A clinic at the Seoul Evangelistic Center}

Source: General Commission on Archives and History, the United Methodist Church, Drew University, Madison, New Jersey.

Bible women played a key mediating role in conveying and distributing the ideals of the Christian home based on what they observed and learned from women missionaries' modern homemaking and child rearing. Their cultural affinity with and intimate knowledge of the Korean home and family made them ideal candidates for delivering new domestic knowledge and adapting that knowledge to the Korean circumstances. In addition, Bible women themselves presented a new model of womanhood. They were literate, earned wages, worked outside the home and exercised leadership roles in public forums such as Bible classes and social service programs. While they advocated a new domesticity, 
their roles and activities took them far beyond conventional domestic duties. As with missionary women, the very emphasis on domesticity and religious piety provided Bible women with social mobility through their literacy and further education and new opportunities to work in the public and gain independence.

\section{Home, sweet home}

The model provided by the missionary home and the lessons Bible women delivered to local Korean women introduced the idea of better homes, more scientific child-rearing and more hygienic family management. This type of domestic knowledge was popular among those drawn to the Christian church and social service programs for the underprivileged. However, a more systematic training program within the framework of formal schooling began when Ewha College established the Department of Home Economics in 1929 after many years of fundraising targeting Christian groups of different denominations as well as individual donors. Ewha College was the only institution of higher learning for women in Korea, and up until that time it had had only two departments - a Department of Literature and a Department of Music. ${ }^{79}$ To be sure, the teaching of domestic skills had been an established practice at mission schools for girls from their inception in the late nineteenth century. Missionary and Korean teachers taught sewing, embroidery and cooking as important skills for girl students. However, "home economics" as a defined discipline with a foundation in legitimate scientific principles was not yet well known. It was only when Harriett Morris (1921-1959), a Methodist missionary and teacher, joined the faculty of Ewha in 1921 that classes in Home Economics were offered to train young women to become experts on home management as well as scientificallyminded housewives. Morris received a B.A. in home economics from the Kansas State University in 1918 and taught the subject for several years before she joined the Korea mission in 1921. At Ewha, she began to introduce Western cooking techniques and Western notions of nutrition that included awareness of calories and vitamins. ${ }^{80}$

79 The essay further elaborates on fund-raising efforts as follows:

The teachers tried hard to get money for another and now the Literary and Music Departments can say they have gained [a] sister. At first the faculty had Yen 10,000 given by Miss Hillman and Miss Morris' father, which was used in preparing classrooms, cooking and sewing laboratories. In America the Southern Methodist women think specially of a Home Economics Department in Korea and decided to send $\$ 1,000$ more a year. The Canadian Woman's Missionary Society also is going to send $\$ 2,000$ next year. With this money Ewha plans to prepare more complete equipment and pay more in teachers' salaries as the number of classes increases. We must pray for the whole college but music and literary girls must pray especially for their baby sister. Let's try hard to help her grow without any interruption. The Korea Mission Field 27(3) (March 1931): 58.

80 Ewha kajŏnghak 50 nyŏnsa, Seoul: Ewha yŏja taehakkyo kajŏng taehak, 1979, pp. 173-75. 
A crucial impetus for further development of the field came in 1923 when Ava B. Milam (b. 1884-d. 1976), a professor of home economics at Oregon State University, visited Ewha as part of her Asian tour from 1922 to 1924 to "spread the gospel of home economics" in the words of Helen Schneider. ${ }^{81}$ She also helped to create a scholarship program at Oregon State for Asian students majoring in home economics. Several Ewha graduates received this scholarship, obtaining training under Milam's supervision and becoming leading experts in the field. The first Korean recipient of this scholarship was Kim Hamna, who received an M.A. from Oregon State in 1927. Around that time Harriette Morris returned to Korea after she had obtained an M.A. at Columbia University. Kim and Morris joined together to advance a plan to establish a Department of Home Economics with generous contributions from donors including Mary Hillman, a former missionary from 1900 to 1928, who had served as acting president of Ewha from 1904 to 1905, and various missionary organisations affiliated with Southern Methodist, Canadian, and Australian churches and the Women's Foreign Missionary Society. In 1929, Ewha was authorised by the government to establish a Department of Home Economics.

The department offered courses not only on domestic skills, such as cooking, dressmaking, housekeeping and child health, but also on pure science subjects, including chemistry, physics, biology and bacteriology. To ensure graduates were well-rounded in both mind and body, the department also required students to take social studies, English, ethics, religion, music and physical education. ${ }^{82}$ Teaching the theories and principles of modern domesticity was not the primary goal. Rather, they heavily emphasised the practical application of domestic and scientific knowledge to the reality of the Korean home. To this end, the department built Home Management House, a two-story structure designed in the style of a Korean home (Figure 5). The house was made available to students with advanced standing, who stayed there for the six months prior to their graduation, practising what they had learned in the classroom in an actual domestic setting, doing all the basic domestic tasks from grocery shopping to planning meals, cleaning the house, gardening and undertaking home improvement projects. They even had a child named Pobae to provide them with first-hand experience in child-rearing (Figure 6). ${ }^{83}$ The faculty also stressed the importance of economic independence by teaching craftswork that could be done at home. ${ }^{84}$

\footnotetext{
81 Helen Schneider, "The professionalization of Chinese domesticity: Ava B. Milam and home economics at Yenching University," in China's Christian Colleges: Cross-Cultural Connections, 1900-1950, ed. Daniel H. Bays and Ellen Widmer, Stanford: Stanford University Press, 2009, pp. 125-46, p. 132. Milam is the author of Adventures of a Home Economist, Corvallis: Oregon State University Press, 1969.

82 Kajŏng kwahak taehak 70 nyŏnsa, Seoul: Ewha yŏja taehakkyo kajŏng kwahak taehak, 1999, p. 23.

83 Kajŏng kwahak taehak 70 nyŏnsa, p. 26.

84 Ewha 100 nyŏnsa p'yŏnch'an wiwŏnhoe, Ewha 100 nyŏnsa (The Hundredth History of Ewha Womans University), Seoul: Ewha yŏja taehakkyo ch'ulp'anbu, 1994, pp. 173-74, 204-07.
} 


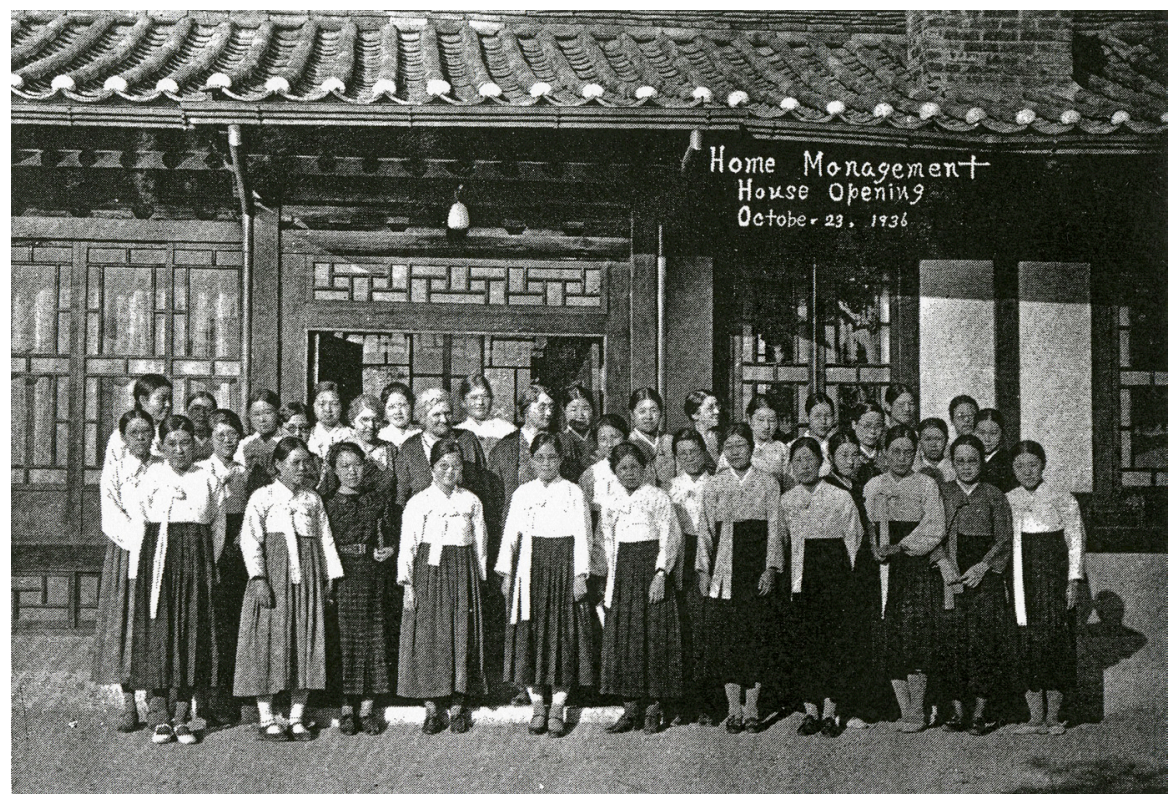

\section{Figure 5. Home Management House Opening in 1936}

Source: Ewha yŏja taehakkyo kajŏng taehak, Ewha kajŏnghak 50 nyŏnsa, Seoul: Ewha yŏja taehakkyo kajŏng taehak, 1979, p. 15.

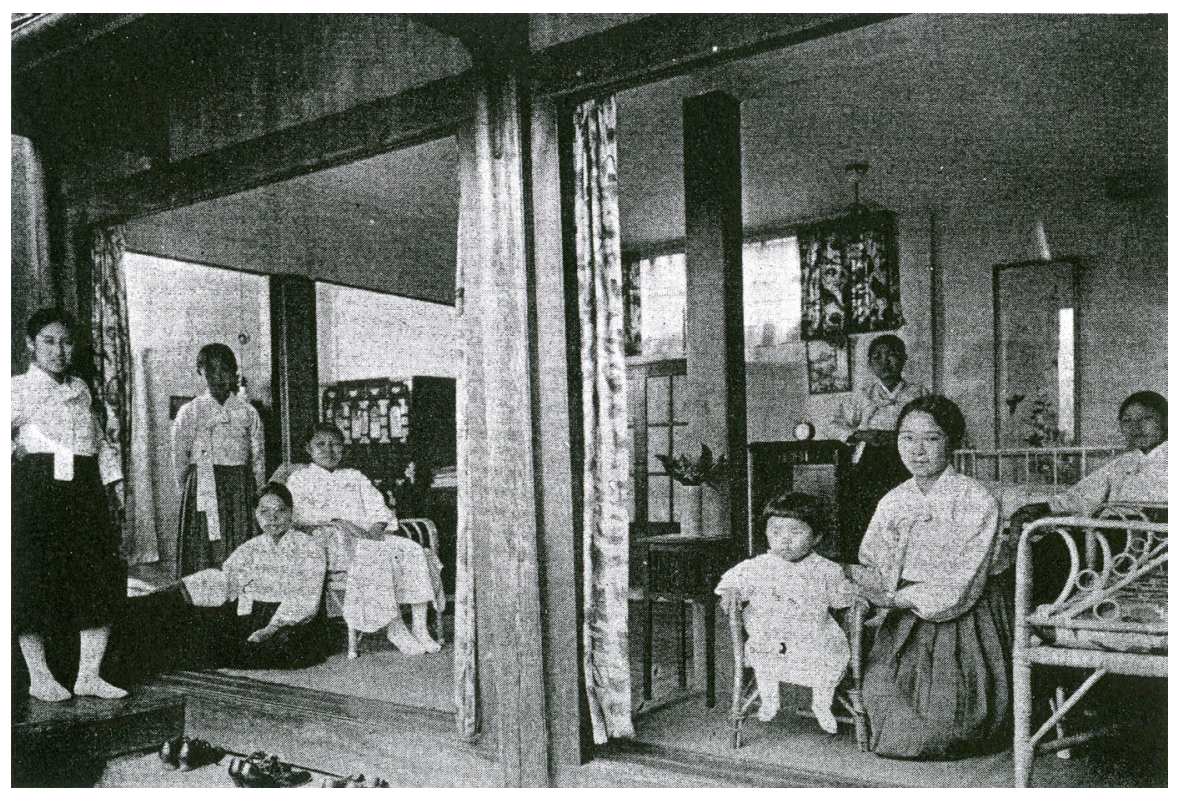

Figure 6. Inside the Home Management House at Ewha

Source: Ewha yŏja taehakkyo kajŏng taehak, Ewha kajŏnghak 50 nyŏnsa, Seoul: Ewha yŏja taehakkyo kajŏng taehak, 1979, p. 14. 
Ewha graduates were spearheading new trends including modern domesticity. Tonga ilbo, a leading daily newspaper, considered graduates of Ewha to be the ones who "hold the key to the Korean culture." ${ }^{15}$ Pang Sinyŏng (1870-1977), the head of Ewha's Home Economics Department in 1936, told a reporter from Tonga ilbo that her department aimed to produce women who were appropriate for Korean homes. Furthermore, Pang emphasised that, "more and more students wanted to study home economics for the purpose of becoming true housewives, and after graduation many of them did become full-time housewives [emphases added]." 86

Ewha authorities' emphasis on Korean homes and true housewives was noteworthy. Korean critics had expressed deep concerns about the missionaries' influence on Korean women because they were certain that these Korean women "would be unfitted to live in the homes from which they had come." 87 They suspected mission schools to be a training ground for Western-style knowledge and practices that would bear little relevance to the Korean reality. At that time, the majority of Koreans were poor peasants and led a lifestyle that was vastly different from that of missionaries and the tiny number of Korean elites. There was not a sizable middle class in Korea that was equivalent to the middle class in the US or Japan at the time. ${ }^{88}$ Even in the 1930s, the overall situation did not change much. In 1932 Ko Yŏngsuk, a woman intellectual, pointed out that women could learn about hygiene, nutrition and scientific child-rearing, but the social reality was that the majority of women simply did not have the time or financial resources that would allow them to practise modern childrearing and home maintenance. ${ }^{89}$ It was one thing to learn about the benefit of "milk, soap, clean clothes, mosquito nets, orange juice, big airy rooms, etc. they [mothers] need for their babies." However, it was another matter entirely whether those mothers could actually afford all these modern products. ${ }^{90}$ In this vein, modern homemaking and child-rearing that was appropriate to the Korean family became a vital issue in granting legitimacy to such education and appealing to the general public. To that end, school authorities tended to stress that they were not interested in teaching "theories" or "academic debates" but rather very practical skills with a strong sense of reality and adaptability.

\footnotetext{
85 Tonga ilbo, 6 February 1936, p. 6.

86 "Kyomun ŭl naonŭn sae ilkkun ŭl ch'ajasŏ" (Visiting newly graduating students), Tonga ilbo, 6 February 1936, p. 6.

87 Marie E. Church and Mrs. R.L. Thomas, "Lulu E. Frey who went to Korea," in The One Who Went and The One She Found, Women's Foreign Missionary Society, 1929, pp. 150-57, pp. 152-53.

88 Kim Sujin, "1920-30 nyŏndae sin yŏsŏng tamnon kwa sangjing ŭi kusŏng" (Excess of the modern: three archetypes of the new woman and colonial identity in Korea, 1920s to 1930s), Ph.D. dissertation, Seoul National University, 2005, pp. 271-72.

89 Ko Yŏngsuk, "Yi Kwangsu ssi ŭi mangdam" (A rash statement: rebuttal to Yi Kwangsu), Sin yŏsŏng 6(11) (1932): 14-16.

90 Choi, Gender and Mission Encounters in Korea, p. 83.
} 
That is, they would teach how to make a stew with locally available ingredients or how to run any kind of household, from one bound by extreme poverty to one of exceeding wealth. ${ }^{91}$

Despite the promise of spreading modern domestic knowledge, there continued to be deep anxiety and suspicion about "educated women," who were often accused of causing instability and disharmony in the family. Ko Hwanggyŏng (b. 1909-d. 2000), who served as head of the Home Economics Department at Ewha from 1940 to 1945, captures public sentiment in her essay on women and the family system in Korea. Taking women's education as the key factor in bringing about major changes to the family system, Ko describes what happens when an educated woman marries and begins her family life. Ko suggests that, given the small number of educated women, they could not immediately change the overall family customs or family traditions, but their preferences may eventually lead to changes in the family that favours, for instance, love marriage over arranged marriage or raising children according to the parents' own beliefs without interference from their in-laws. Ko points out that the majority of educated women still conform to traditional family ethics and practices, but their modern perspectives have brought about a "dual life" (ijung saenghwal) in the sense that they are caught between an ideal and reality; however, the duality confronting the current generation may be resolved in the next generation once this novel, foreign-seeming ideal has become more widespread. ${ }^{92}$

One of the manifestations of the growing desire for modern home life was the circulation and consumption of the song, Home, Sweet Home. The song was so widespread that it was often played at concerts. Young children and students learned the song. ${ }^{93}$ Novelists adopted the image of "home, sweet home" in the portrayal of newly married couples, invoking the idea of a nuclear family based on love, respect and sense of selfhood. ${ }^{94}$ Popular magazines were eager to report on the "home, sweet home" of well-known public figures, embracing the dynamics between the husband and wife, the child-rearing methods that they used, diet and nutrition, and aspects of "culture house" (munhwa chut'aek)modern residential architecture. ${ }^{95}$ This popular image of "home, sweet home" in the 1920s and 1930s is in dramatic contrast with the Korean home American missionaries first observed in the late nineteenth and early twentieth centuries. As mentioned earlier, the medical missionary Mary Cutler described how

\footnotetext{
91 Tonga ilbo, 11 February 1936, p. 5; 29 January 1938, p. 3.

92 Ko Hwanggyŏng, "Chosŏn yŏsŏng kwa kajok chedo" (Korean women and family system), Yŏsŏng 2(10) (October 1937): 36-39.

93 Tonga ilbo, 29 May 1931, p. 3; 11 February 1936, p. 5; 24 January 1936, p. 6.

94 Tonga ilbo, 5 August 1933, p. 2; Pak Yŏnghŭi, "Pallyŏ," Samch'ŏlli 10(1) (1938): 46-48.

95 "Mundan wangnae," Kaebyŏk 2 (December 1934): 84-85; "Sweet home, Yi Kwangsu ssi kajŏng pangmungi," Pyŏlgŏn'gon 34 (November 1930): 110-13; “Tong sŏ nam puk," Samch'ŏlli 5(4) (1933): 102-06; "Kŭriun sinhon sidae," Samch'ŏlli 5(3) (1933): 64-67; “Munsa puin pangmungi," Samch'ŏlli 5(3) (1933): 81-83; "Yŏgija kunsang," Kaebyŏk 4 (March 1935): 74.
} 
marriage for a Korean woman meant that she went to live under the dictates of her mother-in-law rather than creating a distinct home of her own. ${ }^{96}$ Ellasue Wagner said, "A Korean woman has no home, only a house ... a very poor mud hut." The discursive transition from "no home" to "home, sweet home" in Korea was a dynamic transcultural process in which American Protestant missionaries, Bible women and a newly educated class of women in urban and rural areas all actively participated with their own vision of ideal modern domesticity under constrained local circumstances.

\section{Conclusion}

Conforming to the old, while imagining or practising the new, summarily captures the dynamic process of the formation of the modern domesticity that arose through the transcultural interactions between Korean women and American missionaries. The missionary home was an object lesson for "heathens" on the domestic ideal. Missionary women used their homes as a platform where they could engage in evangelical persuasion from their own private space by turning it into a public pulpit. Teaching the gospel went hand in hand with teaching domestic arts because the opportunity to learn those practical domestic skills was what attracted local women. Some of these local women were appointed as Bible women to assist the missionaries in various activities. The unique and crucial role that the Bible women played in the evolution of a new domesticity cannot be emphasised enough. They served as key mediators between missionaries and Koreans, extending the pulpit into the Korean homes they visited in the course of delivering knowledge of the gospel and modern domestic practices to local women. In a significant way, the Bible women belonged to the class of New Women ( $\sin$ yŏsŏng) in that they were literate, possessed modern knowledge of domestic science, earned their own income and worked in the public domain as independent career women. Like missionaries, their piety and sense of domesticity became a means by which women took on more active roles in public. The modern sense of domesticity gives rise to the professionalisation of "home economics." Firmly grounded in the value of domestic skills, the discipline reinforced the old notion that women's proper space is in the private, domestic arena; however, it also established standards for good domestic practice, thereby elevating the work of the home to that of a profession, and created opportunities for women to take on public roles as teachers, professionals and social workers.

96 Cutler, "A Korean wedding," pp. 131-32.

97 Wagner, "A Korean home," p. 90. 
This perforated boundary between the domestic and the public can be best represented in the career of Kim Hwallan (b. 1899-d. 1970), a well-known protégé of missionaries and the first Korean president of Ewha College. When she was interviewed by a women's magazine, she was asked if it would be necessary to provide vocational education at girls' schools. She answered: “Once women get married, they all become housewives. That's why girls' schools offer home economics, teaching them cooking and sewing. Therefore, I don't think it is necessary to offer them vocational education. [If anyone wants to go further] they may go to professional schools." ${ }^{\prime 98}$ It is perhaps ironic that the most prominent woman educator at the only women's college, a woman who had extraordinary accomplishments in virtually every domain, reinforced the idea that the proper place for women is in the domestic realm. Her public prominence as an educator, public intellectual and globally connected elite woman, especially through YWCA and other Christian organisations, is firmly rooted in her contribution to "better homes" appropriate to the Korean context. Coping with the seemingly paradoxical relationship between idealised domesticity and an active public life, Kim and her contemporaries took a long journey to make that paradox less paradoxical.

\section{Acknowledgements}

I would like to thank Margaret Jolly and Dan Devitt for their insightful comments on an earlier version of the chapter. This work was supported through a grant from the Academy of Korean Studies (KSPS) funded by the Korean Government (MOE) (AKS-2011-BAA-2106).

98 Kim Hwallan, “Chinjŏn ŭi yŏjŏng esŏ: kyoyukkye," Sin kajŏng (January 1936): 12-13. 
This text taken from Divine Domesticities: Christian paradoxes in Asia and the Pacific, edited by Hyaeweol Choi and Margaret Jolly, published 2014 by ANU Press, The Australian National University, Canberra, Australia. 